
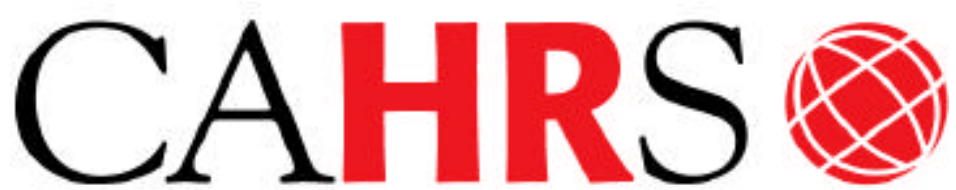

Center for Advanced Human Resource Studies
CAHRS / Cornell University 187 Ives Hall

Ithaca, NY 14853-3901 USA

Tel. $607255-9358$

www.ilr.cornell.edu/CAHRS/

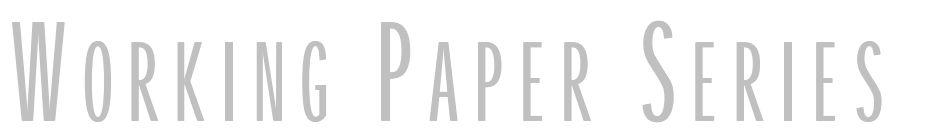

\title{
The Role of Human Resource Practices in Petro-Chemical Refinery Performance
}

Blaine McCormick

Gary C. McMahan

W. Scott Sherman

Patrick M. Wright

Working Paper 97 - 12 


\title{
The Role of Human Resource Practices in Petro- Chemical Refinery Performance
}

\author{
Patrick M. Wright \\ School of Industrial and Labor Relations \\ 393 Ives Hall \\ Cornell University \\ Ithaca, NY 14853-3901 \\ Blaine McCormick \\ Seaver College \\ Business Administration Division \\ Pepperdine University \\ Malibu, CA 90263 \\ W. Scott Sherman \\ Department of Management \\ Texas A\&M University \\ College Station, TX 77843-4221 \\ Gary C. McMahan \\ Department of Management \\ University of Texas at Arlington \\ Arlington, TX 76019 \\ http://www.ilr.cornell.edu/cahrs
}

\section{Authors' Notes}

All correspondence concerning this manuscript should be sent to Patrick M. Wright, School of ILR, 393 Ives Hall, Cornell University, Ithaca, NY, 14853-3901, (607) 255-3429, e-mail: pmw6@cornell.edu.

A previous version of this paper was presented at the 1995 Academy of Management meeting, Vancouver, British Columbia. The authors wish to thank Lee Dyer, Barry Gerhart, Karen Jansen, Julie Goodwin, Kay Perales, Rick Martinez, and Scott Williams for their comments on earlier drafts of this paper.

This paper has not undergone formal review or approval of the faculty of the ILR School. It is intended to make results of Center research available to others interested in preliminary form to encourage discussion and suggestions. 


\title{
The Role of Human Resource Practices in Petro-Chemical Refinery Performance
}

\begin{abstract}
This study examined the impact of Human Resource (HR) practices (selection, training, compensation, and appraisal) and participation on the financial performance of U.S. petrochemical refineries. Survey results from HR and Operations respondents indicated that appraisal and training were significantly related to workforce skills and that training and compensation were marginally related to workforce motivation. In addition, only training was significantly related to refinery performance, although the relationship was negative. However, selection, compensation, and appraisal interacted with participation in determining refinery financial performance such that each of these practices were strongly positively related to financial performance only under highly participative systems. Implications are discussed.
\end{abstract}


The increasingly competitive global economy pushes firms to exploit all of their available resources as a means of achieving competitive advantage. One resource recently recognized as providing a source of competitive advantage is the human resources of the firm, and this recognition has resulted in an expansion of the field of Strategic Human Resource Management (SHRM). Wright and McMahan defined SHRM as "the pattern of planned human resource deployments and activities intended to enable an organization to achieve its goals," (1992: 298). Because firm performance stands out as one major organizational goal, much of the recent SHRM research has been directed at understanding the relationship between Human Resource (HR) practices and firm performance. 
A recent review of studies on the relationship between various $\mathrm{HR}$ practices and firm performance indicated substantial support for the idea that these practices positively impact a variety of performance measures (US Department of Labor, 1993). More recently, Huselid (1995) found that the use of state-of-the-art HR practices provided a substantial relationship with both employee turnover and firm profitability, and Arthur (1994) found that HR practices were related to scrap rates, productivity, and employee turnover. Similarly, MacDuffie (1995) and Ichniowski, Shaw, and Prennushi (1994) derived specific prototypical bundles of HR practices that they explored as determinants of firm performance. Delery \& Doty (1996) found that results-oriented appraisals, profit sharing, and employment security were positively related to Return on Assets and Return on Equity across all strategies in a sample of banks. Similarly, Youndt, Snell, Dean, \& Lepak (1996) found that progressive HR practices were consistent predictors of performance across manufacturing strategies in a sample of manufacturing firms.

While evidence mounts that HR practices are at least weakly related to firm performance, little empirical attention has been paid to exploring the conditions under which these practices or combinations of practices maximally impact firm outcomes such as productivity and profitability. Some authors have argued that HR practices are universally effective (DOL, 1993; Huselid, 1995; Kochan \& Osterman, 1994; Pfeffer, 1994), while others have argued that the effectiveness of HR practices depends partially on the firm's business strategy (Arthur, 1994; Jackson \& Schuler, 1987, Wright \& Snell, 1992).

However, most recently, a configurational view of HR practices has emerged that posits that in order for HR practices to be maximally effective, they must be present in particular "bundles" (Arthur, 1995; Delery \& Doty, 1996: MacDuffie, 1995). This means that HR practices derive their effectiveness from existing as a coherent and internally consistent system of practices. In other words, the effectiveness of any individual HR practices depends upon its pairing with some other HR or management practice. However, little theoretical guidance nor empirical evidence exists for exactly what pairings result in maximum effectiveness. We propose that the positive impact of HR practices on petro-chemical refinery performance is dependent upon those practices being paired with a participative management system. Thus, the purpose of this study is to assess how HR practices and employee participation influence the performance of petro-chemical refineries in the United States.

\section{The Role of Human Resources and HR Practices in Firm Performance}

It is important to clarify our conception of human resources and the role of human resources in firm competitive advantage to understand how HR practices contribute to firm performance. Consistent with Wright, McMahan, \& McWilliams (1994) we define human 
resources as the pool of human capital under the firm's control in a direct employment relationship. Human resource practices, on the other hand, are the organizational activities directed at managing the pool of human capital and ensuring that the capital is employed toward the fulfillment of organizational goals (Schuler \& Jackson, 1987; Schuler \& MacMillan, 1984; Wright \& Snell, 1991).

Given this distinction, we propose that human resource practices are the means through which firms can increase the skills of the workforce, and provide incentives for workforce members to contribute. In addition, the value of these practices will be best achieved only when firms create mechanisms through which employees' contributions can be realized (Wright et al., 1994). The formal development of these hypotheses are presented below.

\section{Hypotheses}

\section{$\underline{\text { HR Practices as Determinants of Workforce Skills and Motivation }}$}

The distinction between human resources and human resource practices is important in terms of understanding the role of HR practices in firm performance because it focuses attention on the fact that HR practices are aimed at developing a skilled and motivated workforce. Flamholtz and Lacey's (1981) application of human capital theory focuses directly on the skills of human beings in organizations. McKelvey (1983), on the other hand, seeks to genotypically classify organizations based on what he refers to as their competencies. In his model, these competencies are found in the knowledges, skills, and abilities (KSA's) of organizational members. Both of these approaches recognize the importance of the individual members of organizations as an important resource. Thus, the human capital pool forms the foundation from which the workforce can influence firm performance (Wright \& Snell, 1991; Wright et al., 1994).

HR practices are essentially the levers by which a pool of human capital can be developed. Through selection practices the firm seeks to identify individuals that possess relevant skills and abilities. Organizations also invest in the continuing skill development of its human capital pool through administering a variety of training aimed at increasing and maintaining each individual's job related skills, and providing development opportunities for individuals which broaden their skill base. Compensations systems are often used to attract individuals who possess the highest levels of skills. Finally, performance appraisal systems promote skill development through identifying specific skill needs of individuals. Thus, through selection, training, compensation, and appraisal of employees firms create a workforce that 
possesses all of the competencies necessary to effectively utilize new technologies and new ways of working.

A firm's human resources also impact firm performance through exhibiting discretionary behavior (e.g., activities, decision making, etc.) that provides value to the firm (MacDuffie, 1995). Much of the writing in the strategic human resource management literature has focused on employee behavior, rather than on employee skills, as the mediator in the relationship between a firm's strategy and its performance (e.g., Jackson, Schuler \& Rivero, 1989; Schuler \& Jackson, 1987; Schuler, 1992). Thus, high performing firms must possess workforce members who are motivated to engage in discretionary behavior directed toward achieving organizationally relevant goals (Wright \& Snell, 1991).

Again, HR practices are the means through which firms seek to motivate employees to engage in discretionary behavior that contributes to the achievement of the firm's goals. Firms can seek to distinguish applicants who are likely to be conscientious workers and who will be unlikely to engage in counterproductive behavior that impedes organizational performance (Ones, Viswesvaran, \& Schmidt, 1993). Similarly, training programs allow the firm to both communicate to employees proper behaviors, and to socialize employees into the norms and culture of the firm. Appraisal systems identify the extent to which individuals are engaging in both functional and dysfunctional behaviors. Through tying rewards to appraisal systems, firms are able to encourage the employees to exhibit those functional behaviors while refraining from the dysfunctional ones, and thus, to act in the interest of the firm (Gerhart \& Milkovich, 1992; Jackson \& Schuler, 1987; Lawler, 1992).

This leads to the following hypothesis:

Hypothesis 1: Human resource practices that consist of an emphasis on selection, training, appraisal, and compensation should be positively related to the skills and motivation of the workforce.

\section{HR Practices and Firm Performance}

In addition to the impact of HR practices on HR skills and motivation, substantial theoretical and empirical attention has been directed at the relationship between various HR practices and firm performance. For example, selection practices have long been argued to result in a dollar-value impact for organizations. Many of the discussions of utility theory (Boudreau, 1983; Schmidt, Hunter, McKenzie \& Muldrow, 1979) have conceptually demonstrated the value that accrues to firms using valid selection practices. This theoretical examination has been buttressed empirically by Terpstra and Rozelle (1993) who found that the use of five selection practices was associated with firm performance. 
With regard to the impact of training on firm performance, MacDuffie and Krafcik (1992) identified training as one of the core components of what they termed "flexible production systems." They found these systems were considerably more productive than traditional mass production systems in terms of exhibiting both lower production times and fewer defects. Holzer, Block, Cheatham, \& Knott (1993) explored the effects of government training subsidies on total hours of training and scrap rates. They found that firms who received the subsidies exhibited a one time increase in the number of hours of training, but that the effects of training were longer lasting in that they also exhibited lower scrap rates in the year after the training.

In spite of the fact that managers are often skeptical about conducting performance appraisals, these systems are an important part of the control systems in organizations (Snell, 1992). Youndt et al. (1996) found that developmental appraisals were related to manufacturing performance after controlling for industry environment and past performance, and that resultsbased appraisals were related to manufacturing performance for firms utilizing a cost strategy. In addition, Delery and Doty (1996) found that appraisal practices were related to Return on Assets and Return on Equity among a sample of banks.

Evidence exists for the effectiveness of incentive systems that tie individual (Gerhart \& Milkovich, 1990) and group rewards (Frost, Wakely, \& Rue, 1974; Welbourne \& Gomez-Mejia, 1995) to organizational performance. Gerhart and Milkovich provided empirical evidence that firms using performance contingent pay for top managers had higher financial performance relative to those that did not. Kauffman (1992) found that companies using an Improshare plan experienced an $8 \%$ median productivity increase in the first year after implementation. The increase jumped to $17.5 \%$ by the third year and levelled off after that. Schuster's (1984) longitudinal study of 28 sites found positive effects of a variety of gainsharing plans on productivity and Hatcher \& Ross (1991) found that changing from individual incentives to gainsharing resulted in a decrease in grievances and an increase in product quality.

Thus, evidence exists for the effectiveness of selection, training, appraisal and compensation systems in impacting firm performance. Thus, this leads to the following hypothesis:

Hypothesis 2: Emphasis on selection, training, appraisal, compensation systems should be positively related to organizational performance.

\section{Employee Participation and Firm Performance}

Research on employee participation has a long history (Cotton, Vollrath, Froggatt, Lengnick-Hall, and Jennings, 1988). Glew, O'Leary-Kelly, Griffin, \& VanFleet defined participation as "a conscious and intended effort by individuals at a higher level in an 
organization to provide opportunities for individuals or groups at a lower level in the organization to have greater voice in one or more areas of organizational performance," (1995: 402). Employee participation programs can take a variety of forms. Cotton et al. (1988) categorized participation according to differences in the form of participation: participation in work decisions where permanent programs exist which allow workers to make direct decisions about the their work; consultative participation where long term programs such as Scanlon plans or quality circles dictate that managers seek subordinate opinions prior to decision making; short-term participation which involves brief formal opportunities for participative decision making about job issues; informal participation which consists of subordinates and managers informally engaging in influence sharing; employee ownership where employees are able to influence management direction by exercising their rights as stockholders; and representative participation, in which employees elect individuals to represent their interests before management. Rather than viewing participation as a particular type, we viewed it as the extent to which employees are allowed to participate in a number of different refinery decisions and activities. Our ten item measure assessed the extent to which operators participated in making decisions such as resolving customer generated problems, working as a member of a problem solving team and setting departmental goals. Thus, our measure specifically tapped all of the types of participation cited by Cotton et al (1988) with the exception of employee ownership and representative management.

Research on the potential organizational benefits of employee involvement/participation systems seems to be mixed. For example, at the individual level of analysis, Wagner and Gooding (1987) found that participation in decision making resulted in improved individual performance. However, Locke and Latham (1990) in their review of participation in goal setting, found little consistent evidence that participation increases motivation. More recently, Wagner (1994) reanalyzed a number of reviews of studies on individual participation and concluded that after eliminating studies where percept-percept correlations inflate the relationship, participation exhibits a statistically significant, but small relationship with individual performance.

Research conducted at the organizational level of analysis has revealed some consistent but inconclusive support for the relationship between participation and firm performance. Levine and D'Andrea Tyson (1990) surveyed the existing research on workplace participation, and found that 14 of 29 studies found improvement while only 2 studies found a negative effect on productivity. In their review of research on employee involvement, McMahan \& Lawler (1995) provide additional evidence of the positive impact of employee involvement in both union and non-union environments. Cooke (1994) found that firms using employee 
participation outperformed other firms in terms of value added net of labor cost per employee, and that this effect was stronger in unionized firms than in non-unionized.

Thus, while much of the research on participation demonstrates some consistent support for the its positive impact on performance, this impact is small and inconclusive. Thus, we propose the following hypothesis.

Hypothesis 3: Employee participation will be positively related to organizational performance.

Employee Participation as Moderator of the HR Practice - Performance Relationship

While the research does not conclusively demonstrate the benefits of employee involvement/participation systems, it does provide evidence that at least under some circumstances, these programs can contribute to firm performance. In fact, Glew et al.'s (1995) model of participation, posited that organizational factors moderate the relationship between participation and both individual and organizational outcomes. This, of course, leads to the questions as to what organizational conditions determine the effectiveness of participation systems.

Much of the research has been based on the assumption that participation increases performance through increasing employee motivation (Glew et al., 1995; Locke \& Latham, 1990). However, recent research and thinking have questioned the assumption that participation impacts performance through increasing motivation. It has become more apparent that the benefits of employee participation are likely to be realized because these employees often have better information for decision making that affects organizational outcomes. Cooke (1994) notes that a basic proposition for how participation programs enhance firm performance is that employees have better and more complete knowledge and information about work tasks and work processes. This places them in better position than managers to identify and correct problems as they arise in the work in order to optimize performance (Levine \& Tyson, 1990; Miller \& Monge, 1986.)

Similarly, Wruck \& Jensen (1994) define "specific knowledge" as knowledge that is costly to transfer inside an organization such as idiosyncrasies of customers, machines, or processes. They note that specific knowledge exists at all levels of the organization: top managers have specific knowledge regarding corporate strategies or interdependencies among departments while employees on the factory floor have specific knowledge regarding a particular machine. They argue that the organizational rules of the game must be structured to provide incentives for individuals to develop and use specific knowledge effectively. This is best achieved through locating decision rights to the level where the specific knowledge exists, in 
other words, to allow lower level employees to influence decisions about work processes at their level.

However, if the major mechanism through which participation affects firm performance is through employees making more effective decisions regarding work processes, then human resource practices become even more important. In order for the full benefits of participation to be realized, the employees must have the skills to make good decisions as well as the desire to do so. Both of these aspects are, again, largely influenced by the firm's selection, training, appraisal and reward systems. For example, Quarry and Rosen (1986) and U.S. General Accounting Office (GAO, 1987) report hypothesized that participation results in increased performance when incentives exist that tie individual outcomes to firm performance.

Thus, it is entirely likely that HR practices or participation alone might be weakly related or even unrelated to performance, but that, consistent with the model proposed here, maximal performance is gained only when they are "bundled" together. In other words, firms will not gain the maximal benefit of HR practices that invest in developing the skills and motivation of the workforce unless the participative systems exist which provide the opportunities for the workforce to impact firm performance. This is especially true in a capital intensive process industry such as refining, since the technology can either be used to limit performance variation among individuals through deskilled work or it can be used to increase performance variation through upskilled work including extensive decision making authority. For example, Wall, Corbett, Martin, Clegg and Jackson (1990) posited two types of technology use in an assembly process. A "specialist control" system was characterized by the operators of the technology having little input into its design, use, and maintenance, resulting in deskilled work and very little participation. On the other hand, a "specialist control" system was characterized by much greater participation and input into system design and maintenance. In this system operators are given much broader responsibilities and deal directly with the majority of operating problems encountered. They found that changing from a specialist control system to an operator control system resulted in lower machine downtime as well as greater intrinsic job satisfaction and reduced work pressure. In a later study, Wall, Jackson, and Davids (1992) found that increased operator control over a robotics line led to a consistent improvement in machine uptime. This improvement initially stemmed reduced lost time per fault, and then later stemmed from improved fault prevention. Similarly in refineries, increasing operator opportunity for participation may increase the potential for performance variance, and thus, the potential for HR practices to positively impact refinery financial performance. 
In essence, we argue that for a highly skilled and motivated workforce to maximally contribute to firm performance, structures and processes must exist that allow the workforce to contribute (Lawler, 1992). Thus, employee involvement/participation systems provide the workforce with the opportunity to share their knowledge, skills, and behaviors (cultivated through HR practices) in ways that benefit the firm. Firms that do not at least allow for employees to contribute ideas and suggestions fail to take full advantage of the skills and motivation of the workforce.

Teams, problem solving groups, employee suggestions In fact, some support for this type of relationship was observed by MacDuffie (1995) in his study of lean production systems within the automobile industry. He distinguished between HRM Policies (measured as recruitment and hiring, contingent compensation, status differentiation, and training, i.e., the types of HR practices assessed in this study) and Work Systems (measured as work made and implemented, job rotation, and decentralization of quality-related tasks, i.e., similar to our variable of participation). His bundles of HRM practices were aimed at increasing the skills and motivation of the workforce. In addition, he argued that the impact of these bundles should only be observed when combined with a participative work system that allows employees to contribute discretionary effort. In fact, he stated:

Innovative human resource practices are likely to contribute to improved economic performance only when three conditions are met: when employees possess knowledge and skills that managers lack; when employees are motivated to apply this skill and knowledge through discretionary effort; and when the firm's business or production strategy can only be achieved when employees contribute such discretionary effort. (MacDuffie, 1995: 199)

In his study, he found support for this hypothesis in that manufacturing sites that paired innovative HRM practices with participative work systems had higher productivity and quality as indicated by the significant HRM Index by Work Systems index interaction term. Thus, consistent with MacDuffie (1995), the following hypothesis is proposed:

Hypothesis 4: The positive impact of selection, training, appraisal, and compensation systems on organizational performance will be stronger when employee participation is high than when participation is low.

\section{Method}

Sample

In much of the work on the relationship between HR practices and firm performance, $H R$ practices have been measured across numerous industries at the corporate level (e.g., Huselid, 1994; Terpstra \& Rozell, 1993). While providing useful information, two potential problems 
exist. First, HR practices, technologies, labor pools and determinants of financial performance differ significantly across industries resulting in potential confounds and/or error variance. While limiting the potential generalizability of the results, focusing a study within a specific industry reduces this error variance.

Second, measurement at this level assumes that every site within the corporation uses the same level and type of HR practices. A more specific and realistic approach would be to examine the HR practices at the place where they are implemented: the specific site (Pils \& MacDuffie, 1994). For these reasons we chose to focus our study on work sites within a specific industry, thus, our sample was drawn from the population of petro-chemical refineries in the United States.

Surveys were mailed to both operations (refinery and operations managers) and human resources (HR manager and Employment Coordinator) employees at all 194 petroleum refineries in the United States as listed by the Department of Energy's Energy Information Administration. Four of the refineries had ceased operations, and the surveys were returned, resulting in a potential sample of 190 .

Much recent research regarding HR practices have focused on the HR practices as they impact a particular key job or class of jobs as opposed to all jobs in a firm (e.g., Arthur, 1992; 1994; Delery \& Doty, 1996; Keefe \& Katz, 1990; MacDuffie, 1995). We chose to assess the variables in this study (HR practices and participation) with regard to the operators in the facility. We chose the operator job because it is considered one of the key jobs in refineries in terms of the percentage of total employees in the job and its impact on refinery performance.

Surveys sent to HR managers asked them to indicate the extent to which their refinery used a variety of selection, training, appraisal, and compensation, and participation practices for managing operators. The HR managers of the refineries oversee all of the HR practices and programs within the refinery, thus, they were in the ideal position to report the formal HR practices used to manage operators. In addition, the survey asked the HR manager to assess the skills and motivation of the operators as well as to indicate the financial performance of the refinery. At least one HR survey was returned from 65 refineries for a response rate of $34 \%$.

One of the potential problems with survey studies is the potential for common method variance which exists when all of the measures in the study are elicited from the same person at the same point in time. In order to avoid this problem, our measure of refinery performance came from the refinery manager. The refinery manager (or operations manager in some cases) is ideally suited to providing the financial performance information because in most cases $\mathrm{s} / \mathrm{he}$ is evaluated on the refinery's profits and sales. Surveys sent to refinery (operations) managers 
asked respondents to assess the skills and motivation of the operators and to reveal the refinery's performance in terms of profit margin during 1993 as well as annual profit growth and annual sales growth over the 1988-1993 period. At least one operations survey was returned from 86 refineries for a response rate of $45 \%$.

In spite of the relatively good response rates from each group, matching surveys (i.e., 1 HR survey and 1 Operations survey) were available for only 38 refineries for an overall response rate of $20 \%$. However, similar to Arthur's (1992; 1994) study, while the small sample presents power problems, it represents $20 \%$ of the entire population of U.S. refineries. To assess the potential for response bias, we compared the refineries in our sample with the population according to the Petroleum Supply Annual published by the Department of Energy. We found no differences in terms of geographic representation. However, the fact that $38 \%$ of the population vs. $20 \%$ of our sample produces less than 30,000 barrels per day indicates that our sample consisted of the larger refineries. This difference is to be expected since the smaller refineries are less likely to have a formal HR department from which the HR survey response would come.

Measures

Selection. Selection was measured with six items adapted from Snell and Dean (1992) which they titled "selective staffing." Sample items from this scale were "How extensive is the employee selection process for the operator job?" (1=Not extensive; 7-Very extensive), "How much importance is placed on the staffing process for operators?" (1=Very Little; 7=A Great Deal) "How many people are involved in the selection decision?" (1=1 person; 7=7 or more persons), and "How many applicants are screened for each operator position?" 1=1; 7=25 or more). The scale exhibited a coefficient alpha reliability of .77 in this study.

Training. Training was measured with 7 items adapted from Snell and Dean (1992) which they titled "comprehensive training." Sample items from this scale were "How extensive is the training for operators?" (1=Not extensive; $7=$ Very extensive), "How much priority is placed on training operators?" (1=Very Little; 7=A Great Deal), "On average, how many hours of formal training does a typical operator receive per year?" ( $1=0$ hours; $7=48+$ hours), and "How much money is spent on training operators?" (1=Almost None; 7=A Great Deal). The scale exhibited a coefficient alpha reliability of .78 in this study.

Compensation. Compensation was measured with 7 items adapted from Snell and Dean (1992) which they titled "equitable rewards." Sample items from this scale include "How would you rate pay levels for operators in your facility relative to competitor facilities in the nation?" (1=Significantly (20\% or more) Below; $7=$ Significantly ( $20 \%$ or more) Above), "How 
closely is pay tied to individual performance for operators in your facility?" ( $1=$ =Not Closely; $7=$ Very Closely), and "To what extent do differences in pay across operators in your facility represent differences in their contribution?" (1=Very Little; 7=A Great Deal). The scale exhibited a coefficient alpha reliability of .63 in this study.

Appraisal. Appraisal was measured with 9 items adapted from Snell \& Dean (1992) which they titled "developmental appraisal." Sample items for this scale include "How much effort is given to measuring employee performance in your facility?" (1=Very Little; 7=A Great Deal), "How closely are raises, promotions, etc., tied to performance appraisal?" ( $1=$ Not Closely; $7=$ Very Closely), "How often is individual performance discussed with operators in your facility?" (1=Rarely; 7=Daily), and "How many people provide input to the performance evaluation of operators?" ( $1=1 ; 7=7$ or more). The scale exhibited a coefficient alpha reliability of .81 in this study.

Employee Participation. Employee participation was measured with ten items that asked the HR respondents to indicate the degree to which operators participated in a variety of activities such as "resolving customer generated problems," "statistically tracking and recording process variation and performance," "working as a member of a problem solving team," and "departmental or functional work area goal setting and planning." The items were presented on a 7-point scale, and the scale exhibited a coefficient alpha reliability of .84. The measure assesses a "comprehensiveness" of participation in terms of the extent to which operators were allowed to participate in a variety of governance decisions.

Operator Skills. Operator skills were measured with five items asking respondents (both HR and operations) the extent to which statements such as "Our operators' job related skills far exceed those of operators at competing facilities," "Our operators display extremely high competence levels compared to operators at competing facilities," and "Compared to other facilities, we have an extremely talented and skilled group of operators" were true. The coefficient alpha reliability for this scale was .81 for the HR respondents and .84 for the Operations respondents. The responses of both respondents were combined to form the final scale. We computed the interrater agreement between the two respondents using the index $\left(r_{w g(j)}\right)$ suggested by James, Demaree, and Wolf (1984). The observed value of .897 indicates sufficient agreement to provide some support for the validity of the measure.

Operator Motivation. Operator motivation was measured with four items asking respondents (both HR and operations) the extent to which statements such as "Our operators are always behaving in ways that help our facility's performance," "Our operators are always contributing in positive ways to facility performance," and "Compared to other facilities, we have 
a highly motivated group of operators" were true. The coefficient alpha reliability for this scale was .91 for both the HR and Operations respondents. The responses of both respondents were combined to form the final scale. We computed the interrater agreement between the two respondents using the index $\left(r_{\mathrm{wg}(\mathrm{j})}\right)$ suggested by James et al. (1984). The observed value of .857 indicates sufficient agreement to provide some support for the validity of the measure.

Financial Performance. Financial performance was measured with three items adapted from Terpstra \& Rozelle (1993). These items asked operations respondents to indicate the facility's profit margin in fiscal 1993 and average annual profit growth during the 1988-1993 time period (both scales: Decline, Break Even, 1-4\%, 5-9\%, 10-14\%, 15-19\%, 20-24\%, and >25\%), and average annual sales growth during the 1988-1993 time period (Decline, 1-4\%, 5-9\%, 10 $14 \%, 15-19 \%, 20-49 \%, 50-99 \%$, and $>100 \%$.) The coefficient alpha reliability for this scale was .75. In addition, we received responses to this measure from both the HR and refinery managers in a subsample of 25 of the refineries. In order to provide some evidence of the validity of this measure, in this subsample we computed the interrater agreement between the two respondents using the index $\left(r_{\text {wg }(j)}\right)$ suggested by James et al. (1984). The observed value of .879 indicates sufficient agreement to provide some support for the validity of the measure. However, in order to eliminate any potential for common method variance, the response of the operations manager was used for the analyses.

Control Variables. Because differences exist across the refineries in terms of the quality of facilities, we sought to control for some of the variables that might confound the results. Technology was assessed by asking the HR person to indicate which statement best described the current technology at the facility ("on the leading edge relative to competitors," "up-to-date relative to competitors," "slightly behind competitors," and "far behind competitors"). Size was assessed by asking the HR respondents to indicate the number of employees in the facility (0$250,251-500,501-1000,1001-2500,2501-4000,>4000)$. Age of the facility was assessed by asking the HR respondents to indicate the year in which the refinery came into existence and subtracting that from 1993.

\section{Results}

Table 1 displays the means, standard deviations, and correlations among the variables. 
Table 1

Means, standard deviations, and intercorrelations among variables.

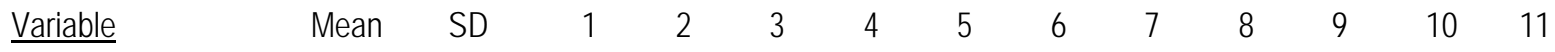

1. Age $\quad 58.4 \quad 25.9 \quad$ -

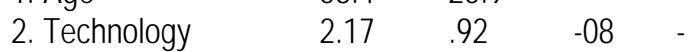

$\begin{array}{llllll}\text { 3. Size } & 378.8 & 354.4 & 39 & -34 & -\end{array}$

$\begin{array}{lllllll}\text { 4. Selection } & 5.55 & .84 & 16 & -12 & 15 & -\end{array}$

$\begin{array}{llllllll}\text { 5. Training } & 5.57 & .84 & 21 & .35 & 50 & 10 & -\end{array}$

$\begin{array}{lllllllll}\text { 6. Compensation } & 3.49 & .78 & -27 & -30 & 04 & -02 & 16 & -\end{array}$

$\begin{array}{lllllllll}\text { 7. Appraisal } & 2.31 & .60 & -19 & -07 & 05 & -01 & 14 & 22\end{array}$

$\begin{array}{lllllllll}\text { 8. Participation } & 2.25 & 1.15 & -01 & -39 & 47 & 13 & 26 & 25\end{array}$

$\begin{array}{lllllllll}\text { 9. EE Skills } & 4.39 & .94 & -17 & -45 & 22 & 17 & 40 & 25\end{array}$

$\begin{array}{lllllllllllll}\text { 10. EE Motivation } & 4.57 & .92 & -12 & -34 & 27 & 06 & 36 & 37 & 16 & 27 & 49 & -\end{array}$

\begin{tabular}{llllllllllllll} 
11. Performance & 2.57 & 1.26 & -12 & -25 & -25 & 09 & -34 & -09 & -06 & -13 & -02 & -07 & - \\
\hline
\end{tabular}

$\mathrm{n}=38 ; \quad \mathrm{r}>.27 \mathrm{p}<.05 ; \quad \mathrm{r}>.40 \mathrm{p}<.01$ (two-tailed)

decimals are omitted from intercorrelations

Hypothesis 1 stated that the HR practices emphasizing selection, training, appraisal, and compensation would be positively related to the skills and motivation of the of operators. this was tested by computing two regressions, regressing skills and motivation, respectively on selection, training, appraisal, and compensation. As Table 2 indicates, appraisal and training were significantly related to the measure of operators' skills. In addition, training and compensation were both marginally $(\underline{p}=.08)$ related to the measure of operators' motivation. Thus, only partial support was demonstrated for Hypothesis 1.

Table 2

Regression results regressing operator skills and operator motivation on HR practices.

\begin{tabular}{|c|c|c|c|c|}
\hline \multicolumn{3}{|c|}{ Operator Skills } & \multicolumn{2}{|c|}{ Operator Motivation } \\
\hline Variables & B-Weight & $\underline{p}$ & B-Weight & $\mathrm{p}$ \\
\hline Selection & .16 & n.s. & .04 & n.s \\
\hline Training & .33 & .05 & .33 & .08 \\
\hline Appraisal & .74 & .01 & .08 & n.s \\
\hline Compensation & .12 & n.s. & .37 & .08 \\
\hline Constant & -.49 & & 1.05 & \\
\hline Total R2 & .43 & .01 & .23 & .10 \\
\hline
\end{tabular}

Note: B-weights and significance for those weights are from the full regression equation.

Hypothesis 2 stated that the HR practices (selection, training, appraisal, \& compensation) would be positively related to the financial performance of the refineries.

Hypothesis 3 stated that employee participation would be related to refinery performance. Hypothesis 4 stated that the positive impact of selection, training, appraisal, and 
compensation systems on refinery performance will only be observed when employee participation is high. In other words, one would expect to find that participation moderates the relationships between each of the HR practices and firm performance. These hypotheses was tested with a series of four hierarchical regressions. In each regression, financial performance was regressed on the control variables in the first step, the focal HR practice in the second step, the participation variable in the third step, and the HR practice by participation interaction in the fourth step. Because the first step is identical in each of these equations, suffice it to note that the control variables accounted for $19 \%$ of the variance in financial performance in all four equations. Support for Hypotheses 2 and 3 would be observed if the focal variables (either the HR practice or participation) explained significant incremental variance in performance when they were entered in their respective steps. Support for Hypothesis 4 would be observed if the HR practice X Participation interaction term explained significant incremental variance in performance when entered in the final step of the regression. The results for these regressions are reported in Table 3.

As can be seen in Table 2, only one of the HR practices (training) explains a significant amount of variance in refinery financial performance, and in this case it was negatively related. Thus, no support was demonstrated for Hypothesis 2.

Also, as can be seen in Table 2, participation failed to account for any significant variance in refinery performance in any of the four equations. It is important to note that it fails to explain significant variance if participation is entered prior to the HR practices as well. Thus, no support was demonstrated for Hypothesis 3.

However, this lack of support for the beneficial impact of HR practices and participation on refinery performance must be tempered in light of the number of significant interactions. In the first equation, the selection by participation interaction accounted for $50 \%$ (p. <.01) of the variance in performance. In the second equation, the training by participation interaction accounted for only an incremental $1 \%$ (n.s.). In the third equation, the compensation by participation interaction accounted for an incremental $13 \%(\underline{p}<.05)$. Finally, in the fourth equation, the appraisal by participation interaction explaining an incremental $23 \%$ ( $\underline{p}<.05)$ of the variance. As can be seen in Figure 1, all of the significant interactions indicate that the impact of selection, compensation and appraisal is positively related to refinery performance when participation is high, but strongly negatively related when participation is low. This indicates support for Hypothesis 4. 


\section{Table 3}

Regression results regressing financial performance on each HR practice, participation, and the interactions. Variables B-Weight

Step 1

Age

Tech

$-.002$

Size

Step 2

Selection

Step 3

Participation

Step 4

Sel X Part

$-.25$

$.001^{*}$

$-3.1^{* *}$

$-8.1^{\star *}$

Step 1

Age

Tech

Size

Step 2

Training

Step 3

Participation

Step 4

Trn X Part

$-.23$

Step 1

Age

Tech

Size

Step 2

Compensation $-1.92^{\star \star}$

Step 3

Participation

Step 4

Pay X Part

1.36 **

$\underline{\mathrm{R}^{2}} \quad \stackrel{\mathrm{p}}{\mathrm{Selection}}$

.19

.08

.02

ns

.01

ns

.50

.00

19

Training

$-.001$

-.68 **

.000

$\begin{array}{rr}. .23 & \\ .83 \\ -.16\end{array}$

.10

.03

$.03 \quad \mathrm{~ns}$

83

.01

ns

Compensation

.19

.08

$-.003$

$-.51^{*}$

.000

Step 1

Age

Tech

Size

Step 2

Appraisal

Step 3

Participation

Step 4

App X Part

-2.18 *

$.61^{*}$

$-.00$

$-.32$

$-.002^{\star *}$

$-2.87^{\star *}$

$-2.63^{\star *}$

$1.25^{\star *}$

$.04 \quad$ ns

$.01 \quad$ ns

.13

.02

.19

Appraisal

.08

Note: B-weights and significance for those weights are from the full regression equation. 


\section{Figure 1}

Interactions Between Human Resource Practices And Participation in Predicting Refinery Financial Performance

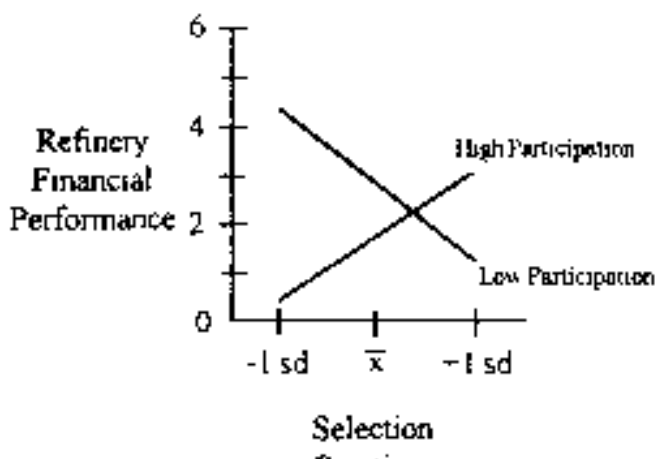

Practices

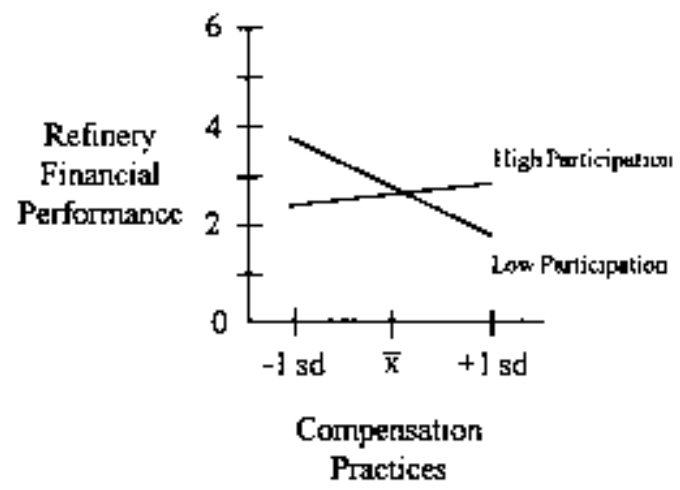

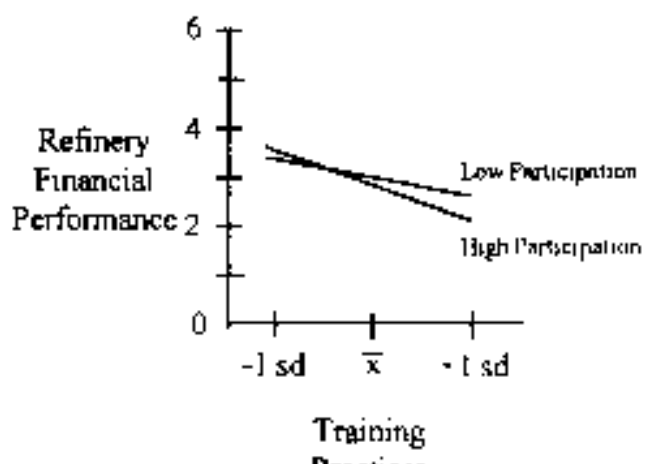

Practices

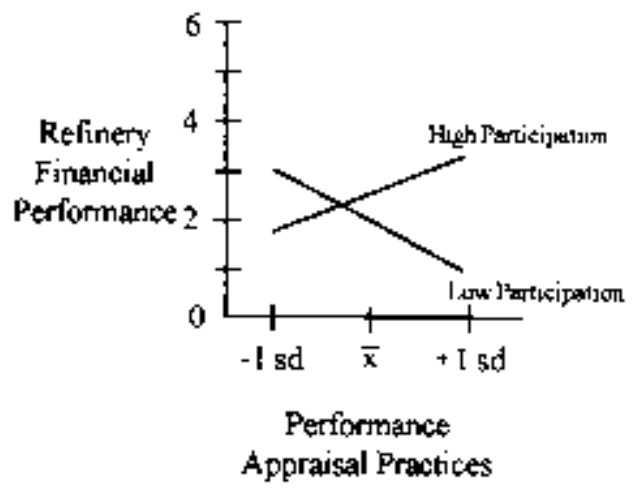

\section{Discussion}

Quinn (1992) noted that in today's organizations where technologies, markets, and capital are similar across competitors, people are playing an increasingly important role in determining firm performance. The results of this study indicate that HR practices positively affect the skills and behaviors of operators, and that the impact of these practices on refinery performance is strongest when they are paired with a system that allows operators to participate in the governance of day-to-day activities. These results have important implications for understanding how a firm's employees can provide a source of competitive advantage.

With regard to the skills of the operators, training and appraisal both exhibited a positive relationship, but selection and compensation did not. While the failure to find a relationship for 
compensation was not extremely surprising, the lack of a relationship for selection was. Arthur (1995) indicated, this may represent the substitutability of HR practices (particularly training and selection) towards achieving certain ends. He noted that some, but not all, workforce skills can be obtained through either establishing selection systems that ensure new hires already possess the skills, or through the application of training programs to instill these skills in employees once they are hired. Also, given the fact that our appraisal measure was one that focused on the developmental aspects of appraisal, the fact that it was related to skills makes theoretical sense.

Regarding the motivation of operators, compensation and training practices were both marginally positively associated to the motivation measure. The compensation measure assessed at least in part the extent to which operators could expect to receive positive outcomes for higher levels of performance. Thus, while not surprising, the results indicate that refineries that tie pay to performance can expect to cultivate a highly motivated workforce. In addition, the positive relationship between training and motivation indicates that refineries that heavily invest in training may reap motivational as well as skill-based rewards.

The failure to find the hypothesized relationship between HR practices and refinery performance might be explained by considering the nature of the petro-chemical industry. Refineries are highly capital intensive, and the industry tends to be characterized by a more traditional control-oriented (Arthur, 1992) approach to managing resources. In many cases the technology used is aimed at decreasing the skill requirements and discretion of operators (Zuboff, 1988). In fact, as can be seen in Table 1, technology is significantly negatively correlated ( $r=-.39$ ) with participation, indicating that many refineries may be trying to reduce the human input into the production process through replacing it with technology. In such cases, investments in extensive HR practices can be quite costly (i.e., costs of training, managerial time spent in the selection and appraisal processes, higher wages, etc.). To incur such costs while seeking to minimize the opportunity for employees to impact refinery performance would logically negatively affect the financial performance of the unit.

Similarly, the control-orientation towards managing human resources helps to understand why participation, by itself, was not positively related to refinery performance. If a refinery were to allow operators to engage in high levels of participation without first ensuring that those operators were highly skilled and committed to the organization, the costs of such participation would likely outweigh its benefits. Thus, these results indicate that the most effective approaches to managing human resources in petrochemical refineries are to either 
simultaneously invest in both HR practices and participation programs or to invest in neither; the lowest financial performance is observed when managers invest in only one or the other.

Finally, the most interesting results were observed with regard to the moderating role that participation played in the relationship between $\mathrm{HR}$ practices and firm performance. The results indicate that efforts to build a skilled and motivated workforce through the application of HR practices such as selection, training, compensation, and appraisal will be for nought unless those employees are provided the opportunities to contribute through participative decision making mechanisms (Department of Labor, 1993; Ichniowski et al, 1994). It may be especially important in capital intensive industries such as petro-chemical refining. In such industries, technology is often used to replace human input, thus, minimizing the potential for performance variation among human actors. However, participatory systems create a much greater potential for performance variation, thus, allowing for the impact of HR practices to be observed.

In fact, these results strongly replicate those of MacDuffie (1995) in automobile assembly plants. While MacDuffie's work utilized an overall HRM index that encompassed the individual HRM practices assessed here, the overall pattern of results are quite similar. In both that and the present study, HR practices seemed to be maximally related to firm performance only when paired with a participative system that allows employees to contribute their discretionary effort toward positive organizational outcomes.

Lawler (1986) defined employee involvement (as distinguished from participation) as having four components: information, knowledge, rewards, and power. He argues that employee involvement is maximally effective only when all four components exist simultaneously. In the context of this study, measure of participation encompassed both information (having access to day-to-day performance information) and power (having influence over decision making). In addition, the HR practices assessed are clearly aimed at the skill and reward components. Thus, the basic tenets of our study seem to be supportive of Lawler's (1992) conceptualization of high-involvement organizations. They are also quite consistent with the calls for moving toward more high performance/high commitment workplaces (Kochan \& Osterman, 1994; Lawler, 1992; Pfeffer, 1993) that entail investing in employee skills, creating incentives for employees to contribute, and providing for employee involvement in decision making (Department of Labor, 1993).

Participation of highly skilled and motivated employees positively impacts performance of refineries for two reasons: efficiency and effectiveness. Because the technology of refineries is easily imitable by competitors (albeit in some cases, at some cost), refineries must compete on the basis of other resources, particularly, human resources. As previously discussed, 
participation allows for greater performance variation from employees, and thus, greater potential for human input to impact performance. Operators control virtually all aspects of the production process and can either negatively or positively impact the productivity, time up, and scrap (or waste) of the petrochemical products. Operators also possess specific knowledge regarding the most efficient means for producing particular products (Wruck \& Jensen, 1994). Thus, when these operators are skilled at monitoring all aspects of the process, desire to ensure that the process is as efficient as possible, and able to make decisions regarding work processes or procedures that ensure efficient production, high financial performance should result.

From an effectiveness standpoint, this focus on a skilled, motivated, and participating workforce also provides a foundation for exploring the link between human resources and strategy, particularly as it pertains to the concept of emergent strategy (Mintzberg, 1978). Mintzberg (1987) contends that realized strategies develop through both a deliberate process and emergent opportunities on which the firm seeks to capitalize. While some of these emergent strategies may be attributed to luck, others can be argued to emerge from the "grassroots" of an organization via participative practices. Thus, facilities that possess highly skilled and motivated employees who are able to actively seek to identify emergent opportunities and then provide participative mechanisms through which these opportunities can be brought to management's attention would be expected to outperform facilities lacking these workforce and workplace characteristics. Certainly future research should examine the role that HR practices can play in eliciting and capitalizing on emergent strategies.

\section{Limitations}

As with any study, some limitations exist with the present study that need to be recognized. First, the relatively small sample created difficulty in finding significant relationships as well as potential generalizability problems. The low power associated with the small sample size was problematic, and likely played a major role in our failure to observe a number of main effects for HR practices and participation on refinery performance. In addition, a low sample size results in greater confidence intervals, and increases the likelihood of finding chance significant relationships opposite the hypothesized direction, such as that observed between training and performance. However, some significant relationships were observed nonetheless. Thus, although a larger sample size would have been desirable, the fact that significant relationships were observed without the statistical power seems to imply that, if anything, our estimates of the relationship of HR practices to refinery performance are conservative. 
Second, as previously discussed, using a sample from within only one industry should be recognized as a potential limit to the generalizability of the results. There is certainly great value in having cross industry studies such as those of Huselid (1994) and Jackson et al. (1989). However, as Eisenhardt (1988) noted, there is also value in studying issues in a single industry. While the latter provide less generalizability than the former, generalizability is never achieved in one study, but rather through multiple replications of results across a variety of subsamples (Berkowitz \& Donnerstein, 1982; Dipboye \& Flanagan, 1979). Greenberg (1987) specifically proposed a strategy of conducting numerous studies on different sets of homogeneous subpopulations in order to determine the boundary conditions of particular theories. While we would not recommend immediately generalizing our results to vastly different industries such as retailing or small batch processing technologies, we would feel quite comfortable recommending some generalizability to other capital-intensive continuous process industries such as pulp and paper manufacturing or steel mini-mills. Certainly we call for future research to replicate these results with larger samples and in other industries.

Third, the self-report survey measures, particularly of the refineries' financial performance can be criticized as being potentially inaccurate. However, we sought to gather these measures from individuals who would be well aware of the facility's performance. The Operations survey was completed by either the refinery manager and/or an operations manager who was his/her direct report and in cases where we had data from two respondents, sufficient interrater agreement was observed. Thus, it seems reasonable to assume that these individuals should have been quite cognizant of the facility's performance on these dimensions. As previously noted, the respondents are most certainly held accountable for these performance measures, thus, it is logical to assume that their reports are relatively accurate.

Similarly, the HR manager should similarly be the best qualified individual to report on the formal HR practices used with regard to operators since s/he is accountable for their development and implementation. In addition, the interrater agreement observed for the operator skills and operator motivation measures achieved sufficient levels to support the contention that these measures were more than simply one person's opinion. Finally, by using different respondents for both the main independent and dependent variables, we eliminated the possibility of common method variance.

Also, with regard to the measurement of HR practices, it is important to note that our measures assessed the HR policies/practices that exist formally within the refinery rather than how those practices actually impact employees through supervision. We recognize that much of HRM is operationalized at the level of the supervisor independent of the formal systems in 
place. However, it was entirely impossible to assess HR practices as operationalized by numerous different supervisors within each refinery in this study. We were attempting to assess the formal HR practices/policies as they had been designed to work by the HR function. We feel relatively safe in the assumption that although not every supervisor will properly implement all HR practices, refineries with sophisticated HR systems developed by the HR department will have a greater level of supervisory compliance than ones where the HR department has not developed such systems at all. While a few exceptions might exist, we think it is illogical to assume that a refinery which has not developed a sophisticated formal HR system of policies and practices will somehow have sophisticated practices evolve among all or a majority of the supervisory personnel.

Also, the measures of practices were not the specific practices such as the use of employment tests, job analysis, etc. that have been used in a number of other studies. For example, Huselid, (1995) and Huselid and Becker (1997) asked respondents to indicate the percentage of employees covered by practices such as employment tests, attitude surveys, and job analysis across an entire organization. While some of the items are phrased at a more general level (e.g., How extensive is the selection process for the operator job?) many of the items do assess HR practices with more specificity than recent measures (e.g., How often is individual performance discussed with operators in your facility? How closely is pay tied to individual performance for operators in your facility? How many different kinds of training programs are available for operators to attend? and How many applicants are screened for each operator position?). In addition, multiple items were used to assess different dimensions of the major HR systems (e.g., multiple items assessing pay level relative to competitors, and multiple items assessing pay for performance links, both sets of which comprise an internally consistent measure of pay practices). Finally, these assessments were made by HR managers assigned to the facility with regard to a single position which constitutes the largest job category in the plant. Thus, there is reason to believe that, in fact, these measures are more meaningful measures of HR practices.

Finally, it is important to recognize the possibility of reverse causation given the cross sectional nature of the study. It is entirely possible that high performing refineries have the slack resources available to invest in more rigorous selection, training, appraisal, compensation, and participation programs. Certainly, future research needs to assess the causal nature of the relationships observed here. 


\section{Conclusion}

In summary, this study demonstrated support for the propositions that HR practices can impact the skills and behaviors of the workforce, and that these practices are maximally effective when paired with a system that allows employees to participate in the day-to-day governance of the workplace. The results support the idea that at least one aspect of SHRM consists of developing the proper configuration of HR practices that will positively impact firm performance. The configuration might best be aimed at developing a skilled and motivated workforce and providing them with participative mechanisms through which they can and will contribute to firm performance.

Consistent with recent conceptualizations of the resource based view of the firm (Barney, 1991; Wernerfelt, 1984), this study supported the notion that HR practices can be used as levers through which firms develop a skilled and motivated workforce that can be a source of competitive advantage (Wright et al., 1994). Given Hansen \& Wernerfelt's (1989) findings that organizational resources (i.e., workforce characteristics) explain much more variance in firm performance than do industry conditions, these results imply that firms would benefit from investing in their employees through the strategic use of HR practices. 


\section{References}

Arthur, J. 1992. The link between business strategy and industrial relations systems in American steel minimills. Industrial and Labor Relations Review. 45: 488-506.

Arthur, J. 1994. Effects of human resource systems on manufacturing performance and turnover. Academy of Management Journal, 37: 670-687.

Arthur, J. 1995. Testing the strategic human resource perspective: Contingency and configurational approaches. Working paper, Purdue University, West Lafayette, IN.

Bacharach. S. 1989. Organizational theories: Some criteria for evaluation. Academy of Management Review, 14: 496-515.

Barney, J. 1991. Firm Resources and Sustained Competitive Advantage. Journal of Management, 17: 99-120.

Bartel, A. In press. Productivity gains from the implementation of employee training programs. Industrial Relations.

Becker, G. 1964. Human Capital. New York: Columbia U. Press.

Berkowitz, L. \& Donnerstein, E. 1982. External validity is more than skin deep: Some answers to criticism of laboratory experiments. American Psychologist, 35: 245-257.

Boudreau, J. 1983. Economic consideration in estimating the utility of human resource productivity improvement programs. Personnel Psychology, 36: 551-576.

Cooke, W. 1994. Employee participation programs, group-based incentives, and company performance: A union-nonunion comparison. Industrial and Labor Relations Review, 47: 594-609.

Cotton, J., Vollrath, D., Froggatt, K., Lengnick-Hall, M., \& Jennings, K., 1988. Employee participation: Diverse forms and different outcomes. Academy of Management Review, 13: 8-22.

Cutcher-Gershenfeld, J. 1991. The impact on economic performance of a transformation in workplace relations. Industrial and Labor Relations Review, 44: 241-260.

Delery, J., \& Doty, H., 1996. Models of theorizing in strategic human resource management: Tests of universalistic, contingency, and configurational performance predictions. Academy of Management Journal, 39: 802-835.

Dipboye, R. \& Flanagan, M. 1979. Research settings in industrial and organizational psychology: Are findings in the field more generalizable than in the laboratory? American Psychologist, 34: 141-150. 
Doty, H., \& Glick, W. 1994. Typologies as a unique form of theory building: Toward improved understanding and modeling. Academy of Management Review, 19: 230-251.

Flamholtz, E. 1985. Human Resource Accounting (2nd. Ed.) San Francisco: Jossey-Bass.

Flamholtz, E., \& Lacey, J. 1981. Personnel Management: Human Capital Theory and Human Resource Accounting. Los Angeles, CA: Institute of Industrial Relations, UCLA.

Frost, C., Wakely, J., \& Ruh, R., 1974. The Scanlon plan for organization development: Identity, participation, and equity. East Lansing, MI: Michigan State Press.

Gerhart, B., \& Milkovich, G. 1990. Organizational differences in managerial compensation and financial performance. Academy of Management Journal, 33: 663-691.

Gerhart, B., \& Milkovich, G. 1992. Employee compensation: Research and practice. In M. Dunnette \& L. Hough (Eds.) Handbook of I/O Psychology (2nd Ed.), 3: 481-570.

Glew, D., O'Leary-Kelly, A., Griffin, R., \& VanFleet, D. 1995. Participation in organizations: A preview of the issues and proposed framework for future analysis. Journal of Management, 21: 395-421.

Greenberg, J. 1987. The college sophomore as guinea pig: Setting the record straight. Academy of Management Review, 12: 157-159.

Hall, R. 1992. Strategic analysis of intangible resources. Strategic Management Journal, 13: $135-144$

Hansen, G. \& Wernerfelt, B. 1989. Determinants of firm performance: Relative importance of economic and organizational factors. Strategic Management Journal, 10: 399-411.

Hatcher, L., \& Ross, T. 1991. From individual incentives to an organization-wide gainsharing plan: Effects on teamwork and product quality. Journal of Organizational Behavior, 12: 169-183.

Holzer, J., Block, R., Cheatham, M., \& Knott, J. 1993. Are training subsidies for firms effective? The Michigan Experience. Industrial and Labor Relations Review, 46: 625-636.

Huselid, M. 1995. Human resource management practices and firm performance. Academy of Management Journal, 38: 635-672.

Huselid, M. \& Becker, B., 1997. The impact of high performance work systems, implementation effectiveness, and alignment with strategy on shareholder wealth. Paper presented at the 1997 Academy of Management Meeting, Boston, MA.

Hunter, J. \& Hunter, R., 1984. Validity and utility of alternative predictors of job performance. Psychological Bulletin, 96: 72-98.

Ichniowski, C., Shaw, K., \& Prennushi, G. 1994. The impact of human resource management practices on productivity. Columbia Business School Working Paper 015. 
Jackson S.E., Schuler, R., \& Rivero, 1989. Organizational characteristics as predictors of personnel practices. Personnel Psychology, 42: 727-786.

James, L., Demaree, R., and Wolf, G. 1984. Estimating Within-Group interrater reliability with and without response bias. Journal of Applied Psychology, 69: 85-98.

Kaufman, R. 1992. The effects of IMPROSHARE on productivity. Industrial and Labor Relations Review, 45: 311-322.

Kochan, T., \& Osterman, P. 1994. The Mutual Gains Enterprise. Cambridge, MA: Harvard Business School Press.

Lawler, E. 1986. High involvement management: Participative strategies for improving organizational performance. San Francisco, CA: Jossey-Bass.

Lawler, E. 1992. The ultimate advantage: Creating the high involvement organization. San Francisco, CA: Jossey-Bass.

Lawler, E., Mohrman, S., \& Ledford, G. 1992. Employee involvement and total quality management. San Francisco, CA: Jossey-Bass.

Levine, D. \& Tyson, L. 1990. Participation, productivity, and the firm's environment. In A. S. Blinder (Ed.) Paying for productivity: A look at the evidence: 183-243. Washington, DC: Brookings Institution.

Locke, E., \& Latham, G., 1990. A theory of goal setting and task performance. Englewood Cliff, $\mathrm{NJ}$ : Prentice-Hall.

MacDuffie, J. (1995). Human resource bundles and manufacturing performance: Organizational logic and flexibile production systems in the world auto industry. Industrial and Labor Relations Review, 48, 197-221.

MacDuffie, J. \& Krafcik, J. 1992. Integrating technology and human resources for highperformance manufacturing. In T. Kochan \& M. Useem (Eds.) Transforming Organizations New York: Oxford University, 210-226.

McMahan, G.C., \& Lawler, E. 1995. The effect of union status on employee involvement: Diffusion and effectiveness. In W. Pasmore \& R. Woodman (Eds.) Research in Organizational Change and Development, Vol. 8, 47-76. JAI Press.

McKelvey, 1983. Organizational Systematics: Taxonomy, Evolution, and Classification. Berkeley, CA: University of California Press.

Miller, K., \& Monge, P., 1986. Participation, satisfaction, and productivity: A meta-analytic review. Academy of Management Journal, 29: 727-753.

Mintzberg, H. 1978. Patterns in strategy formulation. Management Science, 24: 934-948. 
Mintzberg, H. 1987. Crafting strategy. Harvard Business Review, 65(4): 66-75.

Ones, D., Viswevaran, C., \& Schmidt, F., 1993. Comprehensive meta-analysis of integrity test validities: Findings and implications for personnel selection and theories of job performance. Journal of Applied Psychology, 78: 679-703.

Osterman, P. 1994. How common is workplace transformation and who adopts it? Industrial and Labor Relations Review, 47: 173-188.

Pfeffer, J. 1994. Competitive Advantage Through People: Unleashing the Power of the Work Force. Boston, MA: Harvard Business School Press.

Pils, F. \& MacDuffie, J.P. 1994. Linking HR and the Resource based view of the firm: Labor as a strategic asset. Paper presented at the Wharton Conference, Human Resources and the Resource Based View of the Firm.

Quinn, J. 1992. The intelligent enterprise: A new paradigm. The Executive, 6 (4): 48-63.

Schuler, R. 1992. Strategic Human Resource Management: Linking the people with the strategic needs of the business. Organizational Dynamics, Summer, 18-31.

Schuler, R. S. and Jackson, S.E. 1987. Linking competitive strategies with human resource management practices. Academy of Management Executive, 1: 207-219.

Schuler, R.S. and MacMillan, I. 1984. Gaining competitive advantage through human resource practices. Human Resource Management, 23: 241-256.

Schuster, M. 1984. The Scanlon Plan: A longitudinal analysis. Journal of Applied Behavioral Science, 20: 23-28.

Snell, S. 1992. Control theory in strategic human resource management: The mediating effect of administrative information. Academy of Management Journal, 35: 292-327.

Snell, S., \& Dean, J. 1992. Integrated Manufacturing and human resource management: A Human capital perspectiv. Academy of Management Journal, 35: 467-504.

Snow, C., \& Snell, S. 1992. Staffing as strategy. In N. Schmitt and W. Borman (Eds.) Personnel Selection, Vol. 4, San Francisco: Jossey Bass.

Terpstra, D.E., \& Rozell, E.J. 1983. The relationship of staffing practices to organizational level measures of performance. Personnel Psychology. 46: 27-48.

U.S. General Accounting Office 1987. Employee Stock Ownership Plans: Little Evidence on Effects of Corporate Performance. GAO-PEMD-88-1. Washington.

Ulrich, D. 1991. Using human resources for competitive advantage. In R. Kilmann, I. Kilmann, and Associates (Eds.) Making Organizations Competitive. San Francisco, CA: JosseyBass. 
Wagner, J. 1994. Participation's effects on performance and satisfaction: A reconsideration of research evidence. Academy of Management Review, 19:312-330.

Wagner, J., \& Gooding, R., 1987. Shared influence and organizational behavior: A metaanalysis of situational variables expected to moderate participation-outcome relationships. Academy of Management Journal, 30: 524-541.

Wall, T., Corbett, J., Martin, R., Clegg, C. \& Jackson, P. 1990. Advanced manufacturing technology, work design, and performance: A change study. Journal of Applied Psychology, 75: 691-697.

Wall, T., Jackson, P., \& Davids, K. 1992. Operator work design and robotics system performance: A serendipitous field study. Journal of Applied Psychology, 77: 353-362.

Welbourne, T., and Gomez-Mejia, L. 1995. Gainsharing: A critical review and future research agenda. Journal of Management, 21: 559-609.

Wernerfelt, B. 1984. A resource based view of the firm. Strategic Management Journal, 5: 171180.

Williams, M., \& Dreher, G. 1992. Compensation system attributes and applicant pool characteristics. Academy of Management Journal, 35: 571-595.

Wright, P. M., \& McMahan, G. C. 1992. Alternative theoretical perspectives for strategic human resource management. Journal of Management, 18: 295-320.

Wright, P. M. \& Snell, S. A. 1991. Toward an integrative view of Strategic Human Resource Management, Human Resource Management Review, 1: 203-225.

Wright, P., McMahan, G., \& McWilliams, A. 1994. Human resources as a source of sustained competitive advantage: A resource-based view. International Journal of Human Resource Management, 5: 299-324.

Wruck, K. \& Jensen, M. 1994. Science, specific knowledge, and total quality management. Journal of Accounting and Economics, 18: 247-287.

Youndt, M., Snell, S., Dean, J., \& Lepak, D. 1996. Human resource management, manufacturing strategy, and firm performance. Academy of Management Journal, 39: 836-866.

Zuboff, S., 1988. In the age of the smart machine: The future of work and power. New York, NY: Basic Books. 